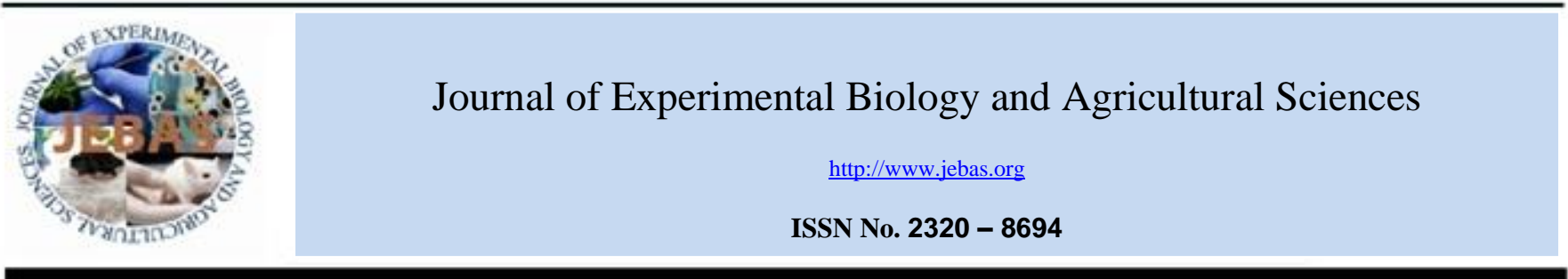

\title{
THE LONG-TERM IMPACT OF WASTEWATER IRRIGATION IN THE ERA OF GLOBAL CONCERN OF ANTIBIOTIC RESISTANCE: A PERSPECTIVE FROM A DEVELOPING COUNTRY
}

\author{
Onthatile Onalenna, Teddie O.Rahube
}

Department of Biological Sciences \& Biotechnology, Faculty of Science, Botswana International University of Science \& Technology, Palapye

Received - August 05, 2019; Revision - September 16, 2019; Accepted -September 28, 2019

Available Online - October 15, 2019

DOI: http://dx.doi.org/10.18006/2019.7(5).481.488

\section{KEYWORDS}

Agriculture

Antibiotic resistance

Public health

Wastewater effluent

\begin{abstract}
Insufficient supply of fresh water remains a global problem, particularly in Africa and Middle East. Using wastewater effluent as an alternative water source for irrigating crops has become a feasible alternative; this relieves demand for fresh water. Wastewater treatment plants (WWTPs) are widely recognized as reservoirs for antibiotic resistant genes (ARGs) that are associated with pathogenesis. This is because WWTPs receive water from various sources and frequently contain antibiotic resistance determinants. Following treatment, wastewater effluent is often discharged into rivers and ponds which are used for irrigation of crops, resulting in the introduction of antibiotic resistant bacteria (ARB) and ARGs into agricultural soils. Many countries have embarked on surveillance and monitoring of antibiotic resistance dissemination in agricultural environments. However, in Botswana no studies have been carried out on dissemination of antibiotic resistance in the environment particularly in agroecosystems. This review will provide a perspective on the long-term impact of wastewater irrigation and a proposal for monitoring antibiotic resistance in a developing country in this era of growing concern on antibiotic resistance.
\end{abstract}

* Corresponding author

E-mail: rahubet@biust.ac.bw (Teddie O.Rahube)

Peer review under responsibility of Journal of Experimental Biology and Agricultural Sciences.

Production and Hosting by Horizon Publisher India [HPI] (http://www.horizonpublisherindia.in/).

All rights reserved.
All the articles published by Journal of Experimental Biology and Agricultural Sciences are licensed under a Creative Commons Attribution-NonCommercial 4.0 International License Based on a work at www.jebas.org.

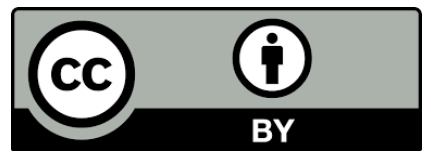




\section{Introduction}

Botswana is a developing country in Africa, with a current population of about 2.37 million, and projected to reach 3 million by 2040 (Akinola et al., 2017). Botswana is attributed to high urbanization rates with a predicted increase rate of $60 \%$ by the year 2026 (Akinola et al., 2017). This puts pressure on the economic status of the country to provide food security for the growing population. There is also need to provide high capacity infrastructures such as wastewater treatment plants (WWTPs). Botswana's climate is semi-arid, and occasionally experience dry spells in the ploughing season, these results in little to no crops harvested contributing to the country's food insecurity (Akinyemi 2017). In order to use wastewater effluent safely, treated wastewater effluent must be in particular standard and follow regulations and guidelines of international and safety standards. However, in most of the developing countries use of wastewater is unregulated, and this could lead to aggravated health risks (Lavrnic et al., 2017). Government of Botswana has implemented interventions as part of the vision 2036 pillar for sustainable economic development towards food security (Mogomotsi et al. 2018). Several horticultural farmers are allocated land near WWTPs to use wastewater effluent and cultivate fresh produce that can be supplied to government schools in an effort to combat under and malnutrition. Produce from these farms also supply to local supermarkets which not only empower the farmers but also contribute in country food security. There is little research conducted on the environmental dimension of antibiotic resistance in Botswana (Sanderson et al., 2018, Tapela \& Rahube 2019), therefore this initiative presents a potential route for antibiotic resistance dissemination in agricultural environments and potentially to humans through consumption of fresh produce.

Antibiotic resistance is a global challenge, the continuous increase of multi-drug resistance bacteria associated with many food borne infectious diseases probes analysis and evaluation of antibiotic resistance dissemination from agricultural environments. This review aims to provide perspective from a developing country on the impact of wastewater irrigation in the era of growing concern on antibiotic resistance. Furthermore, the review also discusses research methodologies for evaluation of antibiotic resistance, and proposal for development of national policies on minimizing antibiotic resistance dissemination through sustainable use of effluent wastewater for agricultural purposes in developing countries.

\section{Antibiotic Resistance and implication to global health}

Antibiotic discovery and commercialization have played a crucial role in revolutionizing medicine. Antibiotics became very crucial especially when performing surgical procedures, organ transplantation as well as managing cancer patients (Munita \&
Arias, 2016). However, more antibiotics are becoming useless due to the increasing antibiotic resistance mechanisms in bacteria. In fact, the World Health Organization (WHO) has recognized antibiotic resistance as one of the top three public health threats of the $21^{\text {st }}$ century (European Commission, 2017). The United States of America, Centre for Disease Control (CDC) estimates that around 23, 000 people lose their lives annually due to infections caused by ARB. The death toll is also predicted to increase up to 300 million premature deaths by 2050 if the development and global spread of antibiotic resistance is not addressed (European Commission, 2017).

\section{The role of wastewater treatment plant in antibiotic resistance development}

Water scarcity is a global challenge, especially Sub-Saharan Africa having higher number of water-stressed countries such as Botswana, Zimbabwe and Kenya (Ozturk, 2017). Tunisia re-uses $75 \%$ of its sewage produced for irrigation of crops (Kerkeni et al., 2007). Similarly Zimbabwe also have semi-arid climate with recurrent drought and wastewater effluent is being used for irrigation of covo (Brassica oleracea variety, acephala) sugar beans (Glycene max) and maize (Zea mays) (Mutengu et al., 2007). Government of Botswana also introduced wastewater irrigation scheme in 2003, initially wastewater effluent was used to irrigate Lucerne in golf courses (Arntzen \& Setlhogile, 2007). Now, vegetable crops are also grown and irrigated with wastewater effluent from the WWTPs, such irrigation scheme is aimed to diversifying the economy and empowering youth (Arntzen \& Setlhogile, 2007).

WWTPs collect wastewater from different environments for controlling environmental pollution by reducing biological oxygen demand, nutrients (nitrogen and phosphorus) and environmental contaminants such as pesticides and heavy metals. In treatment plant wastewater undergoes different stages of treatment to remove as much contaminants as possible, the stages include: preliminary, primary, secondary and tertiary treatment (Qasim 2017). Preliminary water treatment is the removal of waste using screens of any material that floats or readily settles, to avoid blockage of pipes throughout the process. Following pre-screening, primary water treatment involves the removal of suspended solids, through sedimentation. Once the water has passed through primary screening, dissolved solids and nutrients are removed by biological processes such as activated sludge. Secondary treatment converts complex organic compounds into simple volatile compounds such as water, carbon dioxide and methane (Emongor et al., 2005). Tertiary treatment is the last process before water is discharged into the environment; it involves removal of inorganic substances and pathogens through physical removal such as filtration, chemical removal or irradiation methods (Emongor et al., 2005). 


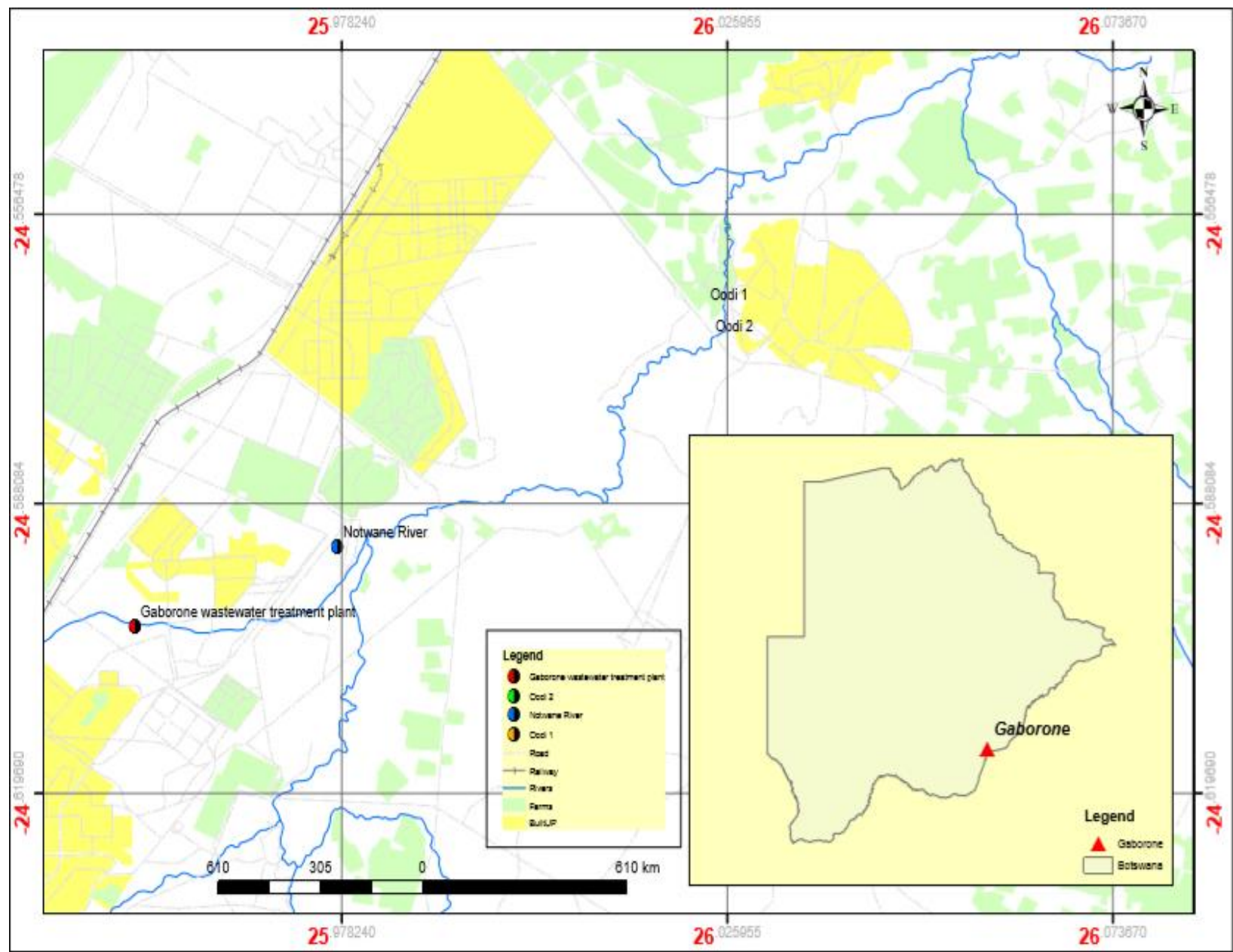

Figure 1 Map showing GWWTP, Notwane river, farmers irrigation scheme sites (Oodi 1, Oodi 2) and other farms around the Notwane river(@ OOnalenna)

WWTPs are widely recognized as reservoirs for ARGs that are associated with pathogenesis (Rahube \&Yost, 2010). WWTPs promote bacteria proliferation because of high bacterial abundance and nutrient density and antibiotic used for these microorganisms induced antibiotic resistance in these bacteria (Zhang et al., 2009). WWTPs have also been shown to promote the incorporation of chromosomally encoded antibiotic resistance genes into plasmids which are then transferred between bacteria (Cattoir et al., 2008). The global gene diversity of antibiotic resistance has been shown wide variation as per regions; the gene abundance corresponds to the regional environmental factors, socio-economic and health status (Hendriksen et al., 2019). A trans-European surveillance of antibiotic resistance in discharged wastewater effluent showed that antibiotic resistance profiles of effluent mirrored the pattern of antibiotic resistance prevalence in clinical settings (Karkman et al., 2019).

\section{Wastewater treatment plants in Botswana}

Gaborone wastewater treatment plant (GWWTP) is the largest treatment plant in Botswana with influent receiving capacity of 40 $000 \mathrm{~m}^{3}$ daily. GWWTP consists of pre-screening, primary and secondary wastewater treatment, it does not have a tertiary stage treatment and instead of this the effluent is discharged into maturation ponds for biological degradation. The final effluent is then discharged into the Notwane river. In dry seasons there is no inflow of water in the river therefore wastewater effluent is directly used for irrigation of fresh produce by farmers along the Notwane river as illustrated in figure 1. The irrigation scheme in Gaborone was shown to be a success in terms of youth empowerment and contribution to food security as the vegetables produced are being supplied to local supermarkets in Gaborone and other regions across Botswana. In addition, the wastewater irrigation scheme is also being introduced in other parts of the country such as Palapye. The central 
regions of Botswana are experiencing rapid population increase due to developments such as opening of Botswana International University of Science \& Technology and expansion of Morupule coal mine. Some parts of the villages have more prominent rural lifestyles where livestock and humans stay in the same vicinity and pit latrine ablutions are still used. However, some parts of villages are more developed with modern infrastructures. Since Palapye is a combination of both rural and urban lifestyles and it makes it a conducive area for rapid dissemination of antibiotic resistan determinants in the environment. Palapye wastewater treatment plant (PWWTP) is located on the outskirts of Palapye, it has a relatively smaller influent receiving capacity of $14000 \mathrm{~m}^{3}$ per day and uses the pond enhancement treatment operation where anaerobic digestion occurs in a series of ponds followed by degradation with biofilters (Shipin et al., 1998). Final effluent from PWWTP is chlorinated before being discharged into a manmade pond where it is used by the public for crop irrigation.

The current wastewater treatment infrastructure in Botswanais not enough to remove the antibiotic residues and ARB in the effluent before being released to the receiving river or environment. Treated wastewater may contain antibiotic resistance determinants even though the levels of indicator microorganisms comply (Lood et al., 2017). A previous study carried out in GWWTP has shown that $\mathrm{ARB}$ and ARG accumulate in the treatment plants and are consequently released into the receiving river, $85.1 \%$ of isolates from GWWTP effluent were found to be resistant to more than one antibiotic tested. Antibiotic resistance genes tetA, mphA, sul1, dfr, int 11 , and $s t r \mathrm{~B}$ were detected in final effluent from the GWWTP. These results showed that antibiotic resistant determinants from WWTPs are potentially introduced to downstream environments (Tapela \& Rahube, 2019).

\section{Impact of Wastewater irrigation on soil microbiome}

Soil is a natural reservoir for antibiotic producing bacteria and approximately $50 \%$ of Actinomycetes microorganisms isolated from soil synthesize antibiotics therefore providing a natural antibiotic residue in soil (Popowska et al., 2012). Anthropogenic activities have been proved to accelerate the development and spread of ARGs in the environment, it is also becoming more evident that ARB and ARGs are widespread in natural untreated soils (Aminov\& Mackie, 2007). Factors influencing ARGs dissipation rates from bacterial hosts introduced into the soil include the transport of bacteria hosting ARGs, the binding of ARGs to soil and the decline of the bacterial hosts (Thanner et al., 2016). The stability of mobile genetic elements (MGEs) is affected by a wide range of parameters such as nutrient availability, temperature, oxygen, $\mathrm{pH}$ and soil type (Rahube \& Yost, 2010).

The use of wastewater effluent for irrigation of crops has been adapted by many African countries such as South Africa, Tunisia and Zimbabwe, this reduces the need for fresh water while improving food security (Khalid et al., 2018). Drip irrigation is the recommended method for wastewater effluent irrigation of crops because it is more efficient as it allows water to drip from soil surface into the soil minimizing evaporation and contact of wastewater effluent with crops. Nonetheless sprinkle irrigation is still practiced and there is direct contact of wastewater effluent with crops which could transfer ARB from effluent directly to crops (Ait-Mouheb et al., 2018). Several studies have shown that irrigation with wastewater effluent increases the nutritive value of the soil which provides a conducive environment for bacterial proliferation (Wafula et al., 2015). Bacteria from wastewater effluent accumulate in soil and can survive for extended periods of time because of nutrient abundance through long-term irrigation. In a study carried out to assess rapid stabilization of the antibiotic resistome in receiving freshwater bodies from wastewater effluent, persistence of wastewater effluent irrigation into the receiving environment was shown to promote the stabilization of resistome from wastewater effluents to the newly formed microbial communities in that environment (Corno et al., 2019). Environmental bacteria can transfer ARGs to clinically relevant pathogens in soil which could potentially be introduced to humans through consumption of raw fruits and vegetables.

\section{Methods for assessing antibiotic resistance dissemination in agricultural soils}

Whole-ecosystem studies are most ideal in research as they better reflect the microbial diversity and changing dynamics in the environment (Tanentzap et al., 2017). On the other hand, microcosm studies are mostly preferred for short-term studies because parameters involved in it can be manipulated and they can be maintained under defined conditions (Eller et al., 2005). Because of higher capacity of experimental controls, microcosm experiments have been successfully used to investigate tetracycline resistance in agricultural soils, the impacts of amoxicillin on bacteria in manure treated soil and the dissemination of multi-drug resistance plasmids in wastewater sludge (Agers $\varnothing$ et al., 2006; Binh et al., 2007; Schmitt et al., 2006).

Further, culture-based methods are globally recognized as conventional methods of surveillance of antibiotic resistance in viable bacterial communities across different environments (Pachepsky et al., 2011). Although in soil samples, non-specific culturing could be a big challenge because generally soil contain abundant bacterial load but use of selective media could be a preferred solution to counteract this challenge. Furthermore, selective media might associate with high false positive rates which lead to inaccurate identification and quantification of bacterial species (Pachepsky et al., 2011). To overcome this situation, confirmatory tests should be carried out for presumptive colonies, these confirmatory tests include microscopy (e.g. Gram 
stain), biochemical detection of expression of metabolic enzymes and gas production (Pachepsky et al., 2011).According to Boehme et al., (2010) approximately $99 \%$ of environmental bacteria cannot be cultured using standard methods and this would be a big drawback of these methods, so it is important that molecular methods should be involved in determining the occurrence diversity and abundance of bacteria in environmental samples.

Polymerase chain reaction (PCR) has become a routine method for detecting ARGs in environmental samples (Zhang \& Fang 2006). It is less time consuming, highly sensitive and more accurate; it is widely used for obtaining information on DNA sequence of interest. PCR has been successfully used to detect ARGs in agricultural environments (Chee-Sanford et al., 2001). However there are downfalls to using conventional PCR, because it depends on sample DNA, efficacy of DNA extraction varies across sample matrices and low DNA yielding samples may compromise the PCR results (Goyer et al., 2012). Moreover, conventional PCR provides information only on presence or absence of the target gene and does not indicate expression levels of the gene. However, detection of the gene is still important because extracellular DNA can be taken up and expressed as another bacterium (Chen \& Dubnau, 2004). PCR products should then be sequenced to confirm the amplified target gene. In Australia the impacts of reclaimed water irrigation on soil antibiotic resistome in urban parks was investigated using high-throughput quantitative PCR and terminal restriction fragment length polymorphism techniques. In this study, diversity, abundance and composition were compared and report showed that irrigation with wastewater effluent significantly increased the abundance and diversity of ARGs in the soil (Han et al. 2016).

Metagenomic sequencing method has gained popularity in molecular characterization of environmental samples (Streit \& Daniel 2017).Community DNA can be sequenced in a single step, and ARGs can be identified by comparison against online databases such as MG-RAST, Integrated Microbial Genome database (IMG) and Comprehensive Antibiotic Resistance Database project (CARD) (Meyer et al., 2008; Kearse et al., 2012; McArthur et al., 2013). Soil metagenomics analysis has shown that soil contains diverse ARGs (Nesme \& Simonet, 2015). Metagenomic analysis has also been used to identify markers of horizontal gene transfer (HGT) such as plasmids, this also give insights on dissemination of ARGs in different environments (Nesme \& Simonet, 2015). Metagenomic analysis has been used previously to compare plasmid encoded ARGs in manure and agricultural soils to determine the dissemination of ARGs from manure to soil (Udikovic-Kolic et al., 2014).

Combining culture-based and molecular methods for surveillance and monitoring of ARGs in agricultural soils allows the ability to detect ARGs, determine the functionality of the genes, identification of microbial taxa harboring individual resistance genes and determination of ARG dissemination in different environments.

\section{Policies for prevention of antibiotic resistance dissemination and sustainable use of effluent wastewater for irrigation purposes}

Recently increase in antibiotic resistance probes action and surveillance of ARGs by global community was reported. The EU has implemented the one health action plan against Antimicrobial Resistance (European Commission, 2017). The goal of this action plan is to preserve the effectiveness of antibiotics in treating humans and animals through reduction in the emergence and spread of AMR, and to increase the development and availability of new effective antimicrobials inside and outside the EU (European Commission, 2017). Most of the member states have implemented national policy plans to combat antibiotic resistance using the "one health approach" however in case of African continent, most of the African countries are at the initial stage of development and implementation of national action plan against antibiotic resistance (European Commission, 2017). The magnitude of antibiotic resistance in African countries still remained unclear, because there is no surveillance system available in these countries (Varma et al., 2018). To address the problems specific to Africa, Centre for Disease Control (CDC) in Africa has established the Antimicrobial Resistance Surveillance Network (AMRSNET) which is aimed at improving surveillance of ARB in animals and humans, delaying the emergence of antibiotic resistance as well as limiting the dissemination of antibiotic resistance (Varma et al., 2018).

Botswana's National Master Plan for Wastewater and Sanitation (NMPWWS) is a long-term strategy which is aimed to evaluate wastewater generation and disposal, as well as its impact on the environment. Further, this plan also aims to develop, implement and regulate environmentally conscious ways for wastewater collection and disposal (Arntzen, 2006). Although Botswana has effluent standards/guidelines, but it lack AMR monitoring which results high risk of $\mathrm{ARB}$ and $\mathrm{ARGs}$ dissemination in downstream receivers i.e. rivers and agricultural soil. Existing water reuse regulations and guidelines do not adequately address the use of wastewater effluent for irrigation of crops with regards to ARB and ARGs being environmental contaminants. It is therefore important to obtain research evidence into policy and practice. Evidence-based policies are important because they are based on research evidence which help in identifying problem, areas, agendas and help in formation and implement of action plans. Collaborations among government, public, private sectors, civil societies and mass media also have important role in getting research evidence, making policies and publicizing (Uzochukwu et al., 2016). 


\section{Conclusion and Recommendations}

The use of wastewater effluent for irrigation is a feasible alternative in African countries with semi-arid climate. However, it has been proven that most of the wastewater treatment facilities are not efficient in removing antibiotic and antibiotic resistant determinants from water which results dissemination of ARB and ARGs into the environment. Further, various studies have been carried out to assess the impact of wastewater irrigation on soil resistome, results of these studies revealed that irrigation with wastewater effluent significantly increased the abundance and diversity of ARGs in the soil. It is therefore crucial that antibiotic resistance dissemination in agricultural soils should be monitored strictly so that timely suitable initiatives can be taken by government of Botswana. For future perspectives, wastewater treatment facilities of Botswana must be assessed for estimating the effectiveness of operating conditions and environmental factors on development and proliferation of ARB in wastewater treatment plants. A national action plan which is based on one health action plan of EU should be adapted to combat the dissemination of antibiotic resistance.

\section{Conflict of interest}

The authors declare that there is no conflict of interest regarding this review.

\section{References}

Agers $\varnothing$ Y, Wulff G, Vaclavik E, Halling-Sørensen B, Jensen LB (2006) Effect of tetracycline residues in pig manure slurry on tetracycline-resistant bacteria and resistance gene tet $(\mathrm{M})$ in soil microcosms. Environment International 32: 876-882.

Ait-Mouheb N, Bahri A, Thayer BB, Benyahia B, Bourrié G, Cherki B, Kitir N (2018) The reuse of reclaimed water for irrigation around the Mediterranean Rim: a step towards a more virtuous cycle. Regional Environmental Change 18: 693-705.

Akinola MO, Lekonpane M, Dada EO (2017) Air quality management in Botswana. Clean Air Journal 27: 43-47.

Akinyemi FO (2017) Climate change and variability in semiarid palapye, eastern Botswana: an assessment from smallholder farmers' perspective. Weather, Climate, and Society 9: 349-365.

Aminov RI, Mackie RI (2007) Evolution and ecology of antibiotic resistance genes. FEMS Microbiology Letters 271: 147-161.

Arntzen J (2006) Water accounting in Botswana: progress and challenges in the economics of Water Management in Southern Africa: An Environmental Accounting Approach: Edward Elgar Cheltenham, UK.
Arntzen JW, Setlhogile T (2007) Mainstreaming wastewater through water accounting: the example of Botswana. Physics and Chemistry of the Earth, Parts A/B/C 32: 1221-1230.

Binh CTT, Heuer H, Gomes NCM, Kotzerke A, Fulle M, Wilke BM, Smalla K (2007) Short-term effects of amoxicillin on bacterial communities in manured soil. FEMS Microbiology Ecology 62: 290-302.

Boehme CC, Nabeta P, Hillemann D, Nicol M-P, Shenai S, Krapp F, Rustomjee R (2010) Rapid molecular detection of tuberculosis and rifampin resistance. New England Journal of Medicine 363: 1005-1015.

Cattoir V, Poirel L, Nordmann P (2008) Plasmid-mediated quinolone resistance pump QepA2 in an Escherichia coli isolate from France. Antimicrobial Agents \& Chemotherapy 52: 3801-3804.

Chee-Sanford JC, Aminov RI, Krapac I, Garrigues-Jeanjean N, Mackie RI (2001) Occurrence and diversity of tetracycline resistance genes in lagoons and groundwater underlying two swine production facilities. Applied and Environmental Microbiology 67: 1494-1502.

Chen I, Dubnau D (2004) DNA uptake during bacterial transformation. Nature Reviews Microbiology 2: 241.

European Commission (2017) A European one health action plan against antimicrobial resistance (AMR) available onhttps://ec.europa.eu/health/amr/action_eu_en, accessed on 06 April 2019.

Corno G, Yang Y, Eckert E-M, Fontaneto D, Fiorentino A, Galafassi S, Di-Cesare A (2019) Effluents of wastewater treatment plants promote the rapid stabilization of the antibiotic resistome in receiving freshwater bodies. Water Research 158: 72-81.

Eller G, Krüger M, Frenzel P (2005) Comparing field and microcosm experiments: a case study on methano-and methylo-trophic bacteria in paddy soil. FEMS Microbiology Ecology 51: 279-291.

Emongor V, Nkegbe E, Kealotswe B, Koorapetse I, Sankwasa S, Keikanetswe S (2005) Pollution indicators in Gaborone industrial effluent. Journal of Applied Sciences 5: 147-150.

Goyer C, Dandie CE, Filion M (2012) Quantification of microorganisms targeting conserved genes in complex environmental samples using quantitative polymerase chain reaction, Quantitative Real-Time PCR. Applied Microbiology 87-106.

Han XM, Hu HW, Shi XZ, Wang JT, Han LL, Chen D, He JZ (2016) Impacts of reclaimed water irrigation on soil antibiotic resistome in urban parks of Victoria Australia. Environmental pollution 211: 48-57. 
Hendriksen RS, Munk P, Njage P, Van-Bunnik B, McNally L, Lukjancenko O, Kjeldgaard J (2019) Global monitoring of antimicrobial resistance based on metagenomics analyses of urban sewage. Nature Communications 10: 1124.

Karkman A, Pärnänen K, Larsson D-J (2019) Fecal pollution can explain antibiotic resistance gene abundances in anthropogenically impacted environments. Nature Communications 10: 80.

Kearse M, Moir R, Wilson A, Stones-Havas S, Cheung M, Sturrock S, Duran C (2012) Geneious Basic: an integrated and extendable desktop software platform for the organization and analysis of sequence data. Bioinformatics 28: 1647-1649.

Kerkeni E, Monastiri K, Seket B, Guediche MN, Cheikh HB (2007) Interplay of socio-economic factors, consanguinity, fertility, and offspring mortality in Monastir, Tunisia. Croatian Medical Journal 48: 701.

Khalid S, Shahid M, Bibi I, Sarwar T, Shah A, Niazi N (2018) A review of environmental contamination and health risk assessment of wastewater use for crop irrigation with a focus on low and highincome countries. International Journal of Environmental Research and Public Health 15: 895.

Lavrnić S, Zapater-Pereyra M, Mancini M-L (2017) Water scarcity and wastewater reuse standards in southern Europe: focus on agriculture. Water, Air, \& Soil Pollution 228: 251.

Lood R, Ertürk G, Mattiasson B (2017) Revisiting antibiotic resistance spreading in wastewater treatment plantsbacteriophages as a muchneglected potential transmission vehicle. Frontiers in Microbiology 8: 2298.

McArthur AG, Waglechner N, Nizam F, Yan A, Azad MA, Baylay AJ, Ejim L (2013) The comprehensive antibiotic resistance database. Antimicrobial Agents \& Chemotherapy 57: 3348-3357.

Meyer F, Paarmann D, D'Souza M, Olson R, Glass E-M, Kubal M, Wilke A (2008) The metagenomics RAST server-a public resource for the automatic phylogenetic and functional analysis of metagenomes. BMC Bioinformatics 9: 386.

Mogomotsi PK, Mogomotsi GE, Hambira WL (2018) Paris agreement on climate change and Botswana's Vision 2036: an examination of linkages. Chinese Journal of Population Resources and Environment 16: 59-66.

Munita JM, Arias CA (2016) Mechanisms of antibiotic resistance. Microbiology Spectrum 4:2.

Mutengu S, Hoko Z, Makoni FS (2007) An assessment of the public health hazard potential of wastewater reuse for crop production: A case of Bulawayo city, Zimbabwe. Physics and Chemistry of the Earth, Parts A/B/C 32: 1195-1203.
Nesme J, Simonet P (2015) The soil resistome: a critical review on antibiotic resistance origins, ecology and dissemination potential in telluric bacteria. Environmental Microbiology17: 913-930.

Ozturk I (2017) The dynamic relationship between agricultural sustainability and food-energy-water poverty in a panel of selected Sub-Saharan African Countries. Energy Policy 107: 289-299.

Pachepsky Y, Shelton D-R, McLain JE, Patel J, Mandrell RE (2011)Irrigation waters as a source of pathogenic microorganisms in produce: a review. Advances in Agronomy 113: 75-141.

Popowska M, Rzeczycka M, Miernik A, Krawczyk-Balska A, Walsh F, Duffy B (2012) Influence of soil use on prevalence of tetracycline, streptomycin, and erythromycin resistance and associated resistance genes. Antimicrobial Agents \& Chemotherapy 56:1434-1443.

Qasim SR (2017) Wastewater treatment plants: planning, design, and operation. Routledge, CRC Press.

Rahube TO, Yost CK (2010) Antibiotic resistance plasmids in wastewater treatment plants and their possible dissemination into the environment. African Journal of Biotechnology 9: 9183-9190.

Sanderson CE, Fox JT, Dougherty ER, Cameron A, Alexander KA (2018) The changing face of water; a dynamic reflection of antibiotic resistance across landscapes. Frontiers in Microbiology 9: 1894.

Schmitt H, Stoob K, Hamscher G, Smit E, Seinen W (2006) Tetracyclines and tetracycline resistance in agricultural soils: microcosm and field studies. Microbial Ecology 51: 267-276.

Shipin OV, Meiring PG, Rose PD (1998) PETRO [R] system: A low-tech approach to the removal of waste-water organic (incorporating effective removal of micro-algne by the trickling filter). Water- SA Pretoria 24: 347-354.

Streit WR, Daniel R (2017) Metagenomics. Springer New York.

Tanentzap AJ, Szkokan-Emilson EJ, Desjardins CM, Orland C, Yakimovich K, Dirszowsky R, Gunn J (2017) Bridging between litterbags and whole-ecosystem experiments: a new approach for studying lake sediments. Journal of limnology 76: 2.

Tapela K, Rahube TO (2019) Isolation and antibiotic resistance profiles of bacteria from influent, effluent and downstream: A study in Botswana. African Journal of Microbiology Research 13: 279-289.

Thanner S, Drissner D, Walsh F (2016) Antimicrobial resistance in agriculture. MBio 7: e02227-02215. 
Udikovic-Kolic N, Wichmann F, Broderick NA, Handelsman J (2014) Bloom of resident antibiotic-resistant bacteria in soil following manure fertilization. Proceedings of the National Academy of Sciences 111: 15202-15207.

Uzochukwu B, Onwujekwe O, Mbachu C, Okwuosa C, Etiaba E, Nyström ME, Gilson L (2016) The challenge of bridging the gap between researchers and policy makers: experiences of a Health Policy Research Group in engaging policy makers to support evidence informed policy making in Nigeria. Globalization and Health 12: 67.

Varma JK, Oppong-Otoo J, Ondoa P, Perovic O, Park BJ, Laxminarayan R, Ihekweazu C (2018) Africa Centres for Disease Control and Prevention's framework for antimicrobial resistance control in Africa. African Journal of Laboratory Medicine 7: 1-4.

Wafula D, White JR, Canion A, Jagoe C, Pathak A, Chauhan A (2015) Impacts of long-term irrigation of domestic treated wastewater on soil biogeochemistry and bacterial community structure. Applied \& Environmental Microbiology 81: 7143-7158.

Zhang XX, Zhang T, Fang HH (2009) Antibiotic resistance genes in water environment. Applied Microbiology\& Biotechnology 82: $397-414$.

Zhang T, Fang HH (2006) Applications of real-time polymerase chain reaction for quantification of microorganisms in environmental samples. Applied Microbiology and Biotechnology 70: 281-289. 